\title{
Novel Associations of BST1 and LAMP3 With REM Sleep Behavior Disorder
}

Kheireddin Mufti, MSc, Eric Yu, BSc, Uladzislau Rudakou, MSc, Lynne Krohn, MSc, Jennifer A. Ruskey, MSc, Farnaz Asayesh, MSc, Sandra B. Laurent, BTS, Dan Spiegelman, MSc, Isabelle Arnulf, MD, PhD, Michele T.M. Hu, MBBS, PhD, Jacques Y. Montplaisir, MD, PhD, Jean-François Gagnon, PhD, Alex Desautels, MD, PhD, Yves Dauvilliers, MD, PhD, Gian Luigi Gigli, MD, Mariarosaria Valente, MD, Francesco Janes, MD, PhD, Andrea Bernardini, MD, Birgit Högl, MD, Ambra Stefani, MD, Evi Holzknecht, MD, Karel Sonka, MD, PhD, David Kemlink, MD, PhD, Wolfgang Oertel, MD, Annette Janzen, MD, Giuseppe Plazzi, MD, Elena Antelmi, MD, PhD, Michela Figorilli, MD, PhD, Monica Puligheddu, MD, PhD, Brit Mollenhauer, MD, Claudia Trenkwalder, MD, Friederike Sixel-Döring, MD, Valérie Cochen De Cock, MD, PhD, Christelle Charley Monaca, MD, PhD, Anna Heidbreder, MD, Luigi Ferini-Strambi, MD, Femke Dijkstra, MD, Mineke Viaene, MD, PhD, Beatriz Abril, MD, Bradley F. Boeve, MD, Jean-François Trempe, PhD, Guy A. Rouleau, MD, PhD, FRCPC, FRSC, Ronald B. Postuma, MD, MSc, and Ziv Gan-Or, MD, PhD

Neurology ${ }^{\circledR}$ 2021;96:e1402-e1412. doi:10.1212/WNL.0000000000011464

\section{Abstract}

\section{Objective}

To examine the role of genes identified through genome-wide association studies (GWASs) of Parkinson disease (PD) in the risk of isolated REM sleep behavior disorder (iRBD).

\section{Methods}

We fully sequenced 25 genes previously identified in GWASs of PD in a total of 1,039 patients with iRBD and 1,852 controls. The role of rare heterozygous variants in these genes was examined with burden tests. The contribution of biallelic variants was further tested. To examine the potential effect of rare nonsynonymous BST1 variants on the protein structure, we performed in silico structural analysis. Finally, we examined the association of common variants using logistic regression adjusted for age and sex.

\section{Results}

We found an association between rare heterozygous nonsynonymous variants in BST1 and $\operatorname{RBD}(p=0.0003$ at coverage $>50 \times$ and 0.0004 at $>30 \times$ ), driven mainly by 3 nonsynonymous variants (p.V85M, p.I101V, and p.V272M) found in $22(1.2 \%)$ controls vs $2(0.2 \%)$ patients. All 3 variants seem to be loss-of-function variants with a potential effect on the protein structure and stability. Rare noncoding heterozygous variants in LAMP3 were also associated with $\operatorname{RBD}(p=0.0006$ at $>30 \times)$. We found no association between rare heterozygous variants in the rest of genes and iRBD. Several carriers of biallelic variants were identified, yet there was no overrepresentation in iRBD.

\section{Conclusion}

Our results suggest that rare coding variants in BST1 and rare noncoding variants in LAMP3 are associated with iRBD. Additional studies are required to replicate these results and to examine whether loss of function of BST1 could be a therapeutic target.

\author{
Correspondence \\ Dr. Gan-Or, \\ ziv.gan-or@mcgill.ca
}

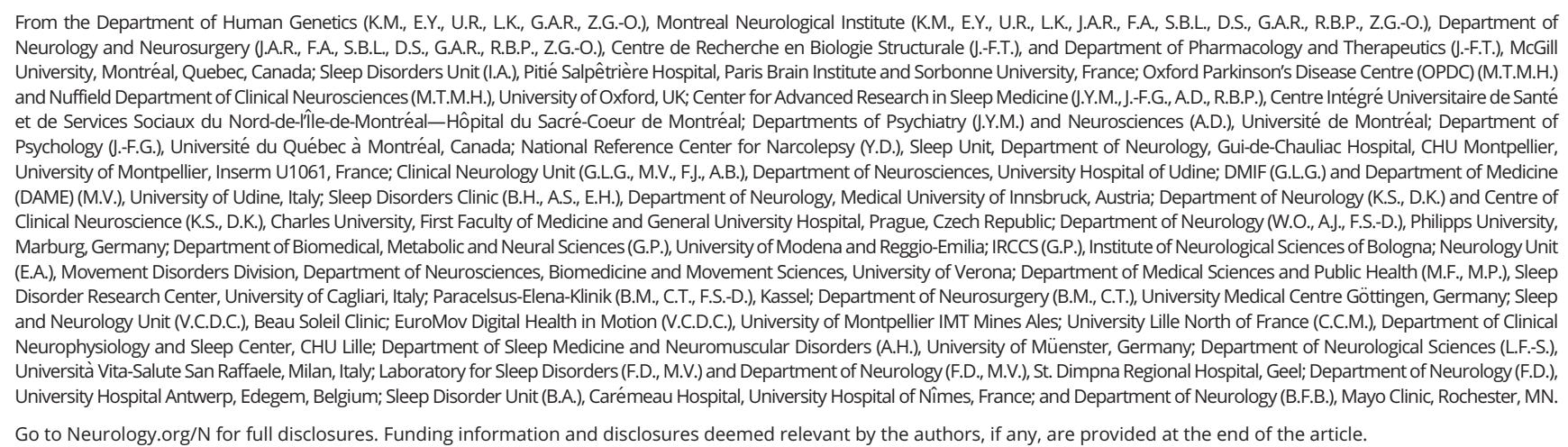
The Article Processing Charge was funded by NIHR UK.

This is an open access article distributed under the terms of the Creative Commons Attribution License 4.0 (CC BY), which permits unrestricted use, distribution, and reproduction in any medium, provided the original work is properly cited. 


\section{Glossary}

DLB = dementia with Lewy bodies; GWAS = genome-wide association study; iRBD = isolated REM sleep behavior disorder; LD = linkage disequilibrium; $\mathbf{M A F}=$ minor allele frequency; $\mathbf{M S A}=$ multiple system atrophy; PD = Parkinson disease; SKAT = sequence kernel association test; SKAT-O = optimized SKAT; UTR = untranslated region.

Isolated REM sleep behavior disorder (iRBD) is a prodromal synucleinopathy; $>80 \%$ of patients with iRBD will eventually convert to Parkinson disease (PD; $\approx 40 \%-50 \%$ of patients), dementia with Lewy bodies (DLB) or unspecified dementia $(40 \%-50 \%)$, or, in much fewer cases, multiple system atrophy (MSA; 5\%-10\%). ${ }^{1,2}$ While our understanding of the genetic background of DLB or MSA is limited, 80 genetic loci have been found to be associated with PD risk discovered through genome-wide association studies (GWASs), ${ }^{3,4}$ and several genes have been implicated in familial PD. ${ }^{5-7}$

Recent studies have suggested that there is some overlap between the genetic backgrounds of $\mathrm{RBD}$ and $\mathrm{PD}$ or DLB, yet this overlap is only partial. $G B A$ variants are associated with iRBD risk, PD, and DLB, ${ }^{5,8}$ but pathogenic LRRK2 variants are associated only with $P D$, not with $i R B D$ and DLB. ${ }^{7,9,10}$ MAPT and APOE haplotypes are important risk factors of PD and DLB, respectively, ${ }^{11,12}$ but neither is linked to iRBD. ${ }^{11,13}$ In the SNCA locus, specific variants in the $3^{\prime}$ untranslated region (UTR) are associated with PD but not with iRBD, and other, independent variants at $5^{\prime}$ UTR are associated with PD, iRBD, and DLB. ${ }^{14}$

In the current study, we aimed to examine whether rare and common variants in 25 PD-related GWAS genes are associated with iRBD. Coding regions, exon-intron boundaries, and $3^{\prime}$ and $5^{\prime}$ UTRs were fully captured and sequenced. We then performed different genetic analyses to investigate the association of these genes with iRBD.

\section{Methods}

\section{Standard Protocol Approvals, Registrations, and Patient Consents}

The study participants signed informed consent forms at enrollment in the study, and the institutional review boards have approved the study protocol.

\section{Study Population}

This study included a total of 2,891 participants: 1,039 unrelated individuals who were diagnosed with iRBD (based on the International Classification of Sleep Disorders criteria, version 2 or 3 ) and 1,852 controls, all of European ancestry. The patients with iRBD and controls were recruited through 18 centers in Canada and Europe, including centers from France, Germany, Austria, the United Kingdom, Czech Republic, Italy, and Belgium. Diagnosis was performed with video polysomnography, the gold standard for iRBD diagnosis, by sleep specialists and neurologists. At recruitment, none of the patients had an overt neurodegenerative disease (PD, DLB, MSA, etc), which defined them as having iRBD. In the current study, we had follow-up data available for 540 patients with iRBD, 190 of whom (35\%) had converted since recruitment to PD, DLB, MSA, or other overt neurodegenerative disease. The controls were not examined by polysomnography, but because only $1 \%$ of them are expected to develop iRBD, it is unlikely that this can affect the results. Details on age and on sex of the participants have been given previously ${ }^{15}$ (data available from Dryad, table e-1, doi. org/10.5061/dryad.vt4b8gtqd). Differences in age and sex were taken into account as needed in the statistical analysis. All patients and controls were of European ancestry (principal component analysis of GWAS data was used to confirm ancestry compared to data from HapMap version 3 and human genome version 19/GRCh37).

\section{Selection of Genes and Genetic Analysis}

We designed and performed the study before the publication of the recent PD GWAS ${ }^{3}$; therefore, the genes for analysis were selected from previous GWASs. ${ }^{16,17}$ A total of 25 genes were selected for analysis: ACMSD, BST1, CCDC62, DDRGK1, DGKQ FGF20, GAK, GPNMB, HIP1R, ITGA8, LAMP3, MAPT, MCCC1, PM20D1, RAB25, RAB29, RIT2, SETD1A, SLC41A1, STK39, SIPA1L2, STX1B, SYT11, TMEM163, and USP25. We selected the genes for at least 1 of the following reasons: the gene has a quantitative trait loci association, the gene is expressed in the human brain, the gene potentially interacts with known PD-associated genes, or the gene is involved in pathways implicated in PD, e.g., the autophagy-lysosomal pathway, mitochondria quality control, and endolysosomal recycling. The 25 genes were fully captured (coding sequence and $3^{\prime}$ and $5^{\prime}$ UTRs) as reported previously with molecular inversion probes. ${ }^{18}$ The protocol is available on github.com/gan-orlab/MIP_protocol. Table e-2 (doi.org/ $10.5061 /$ dryad.vt4b8gtqd) details the probes used in the current study for the molecular inversion probes capture. After the capture, we performed next-generation sequencing with the Illumina HiSeq 2500/4000 platform at the Génome Québec Innovation Centre. Sequencing reads were aligned to the human genome version 19 reference genome with the Burrows-Wheeler Aligner. ${ }^{19}$ We then used the Genome Analysis Toolkit (version 3.8) for quality control and to call variants ${ }^{20}$ and ANNOVAR for variant annotation. ${ }^{21}$ We extracted the variant frequencies for the detected variant from the Genome Aggregation Database. $^{22}$ 


\section{Quality Control}

To perform quality control, we used PLINK version $1.9 .{ }^{23} \mathrm{We}$ excluded variants with a significant deviation (threshold set at $p=0.001$ ) from Hardy-Weinberg equilibrium among controls. Variants with $<25 \%$ of their reads with a variant call were also excluded. To filter out variants with low genotyping rate, we set the threshold for inclusion at $>90 \%$. This threshold was also used to exclude samples from individuals with low call rates. When missingness rate was different among patients and controls (at $p<0.05$ ), we excluded these variants as well. Variants with genotype quality score of $<30$ were further excluded. Rare variants (minor allele frequency $[\mathrm{MAF}]<1 \%$ ) were included according to 2 coverage thresholds, $>30 \times$ and $>50 x$, and all analyses were repeated with these thresholds. For the analysis of common variants, coverage of $>15 \times$ was used.

\section{Statistical Analysis}

To test whether rare heterozygous variants (defined by MAF $<1 \%$ ) in each of our target genes are associated with iRBD, we performed sequence kernel association test (SKAT; R package $)^{24}$ and optimized SKAT (SKAT-O) on different groups of variants, which included all rare variants with $\mathrm{MAF}<1 \%$, variants that are potentially functional (including splicing, nonsynonymous, stop-gain, and frameshift variants), only loss-of-function variants (stop-gain, frameshift and splicing), and only nonsynonymous variants. In addition, we further used the Combined Annotation Dependent Depletion score to test whether rare variants that are predicted to be pathogenic (based on a threshold of $\geq 12.37$, which represents $2 \%$ of the variants predicted to be the most deleterious) are enriched in patients with iRBD. To test the association between biallelic variants and iRBD risk, we used a threshold of MAF $<0.1 \%$ and examined whether there is enrichment of patients who carry 2 such variants compared to controls using the Fisher exact test. Variants included in this analysis were splicesite, nonsynonymous, stop-gain, or frameshift variants. To properly account for multiple comparisons, in each analysis, we applied Bonferroni correction that took into consideration the number of genes that were tested and the fact that the tests were done in 2 different depths of coverage, $>30 x$ and $>50 x$. Therefore, when examining the association of 25 genes in 2 different depths of coverage, we set the threshold for statistical significance in this case at $p=0.05 / 50=0.001$. To test for association of common variants (MAF $>0.01$ ), we used logistic regression adjusted for sex and age with PLINK version 1.9. Linkage disequilibrium (LD) between the variants we found and the respective GWAS top hits was examined with the reference cohort of non-Finnish European embedded in LDlink (ldlink.nci.nih.gov/). ${ }^{25}$ We used the Genotype-Tissue Expression database (GTEx; gtexportal.org) to examine the effects of common variants on gene expression. We further performed in silico structural analysis of BST1 to test whether the rare coding variants that were found to be associated with iRBD in our analysis could potentially affect the enzyme structure and activity. The atomic coordinates of human BST1 bound to ATP- $\gamma$-S were downloaded from the Protein Data
Bank (ID lisg). We evaluated the steric clashes caused by the variants we identified using the mutagenesis toolbox in PyMol version 2.2.0.

\section{Data Availability}

Data after processing that were used for the analyses in the current study are found in the supplementary tables (data available from Dryad, tables e-1-e-7, doi.org/10.5061/dryad. vt4b8gtqd). The raw data can be requested from the corresponding author and will be shared anonymized.

\section{Results}

\section{Coverage and Identified Variants}

The average coverage of the 25 genes analyzed in this study was $>647 \times$ (range $73 \times-1,162 \times$, median $790 \times$ ). An average of $95 \%$ of the target regions were covered with $>15 \times, 93 \%$ with $>30 \times$, and $90 \%$ with $>50 \times$. The average coverage of each gene and the percentage of the nucleotides covered at $15 \times, 30 \times$, and $50 \times$ are detailed in table e-3 (data available from Dryad, doi.org/10.5061/dryad.vt4b8gtqd). Finally, there were no differences in the coverage between patients and controls. A total of 1,189 rare variants were found with coverage of $>30 \times$ and 570 rare variants with coverage $>50 \times$ (data available from Dryad, table e-4). We identified 125 common variants across all genes (data available from Dryad, table e-5) with a coverage of $>15 x$.

\section{Rare Heterozygous Variants in BST1 and LAMP3 Are Associated With iRBD}

To examine whether rare heterozygous variants in our genes of interest may be associated with iRBD risk, we performed SKAT and SKAT-O tests, repeated twice for variants detected at depths of coverage of $>30 \times$ and $>50 \times$ (see Methods). Table e-4 (data available from Dryad, doi.org/10.5061/dryad. vt4b8gtqd) details all rare heterozygous variants identified in each gene and included in the analysis. We applied both SKAT and SKAT-O on 5 different groups of variants: all rare variants, all potentially functional variants (nonsynonymous, splice site, frameshift, and stop-gain), loss-of-function variants (frameshift, stop-gain, and splicing), nonsynonymous variants only, and variants with Combined Annotation Dependent Depletion score $\geq 12.37$ (table 1). The Bonferroni-corrected $p$ value threshold for statistical significance was set at $p<0.001$ after correction for the number of genes and depths of coverage.

We found a statistically significant association of rare heterozygous functional variants in BST1 (SKAT $p=0.0004$ at $>30 \times$ and $p=0.0003$ at $>50 \times$ for rare functional variants), seen more in controls than in patients with iRBD. This association is driven mainly by the nonsynonymous variants p.V85M (rs377310254, found in 5 controls and 0 patients), p.I101V (rs6840615, found in 7 controls and 0 patients), and p.V272M (rs144197373, found in 10 controls and 2 patients). Overall, these variants were found in $22(1.2 \%)$ controls vs 2 
(0.2\%) patients. Of these 2 patients, 1 had self-reported age at onset of 25 years (not confirmed by polysomnography at the time); he was 75 years old at the time of the study and did not convert to an overt synucleinopathy. The second patient had age at onset of 71 years (compared to an average age at onset of 61 years in the entire cohort) and converted to DLB at the age of 73 .

Another statistically significant association was found between rare variants in $L A M P 3$ gene and reduced iRBD risk in SKAT-O analysis. This association is driven by 2 noncoding variants ( 1 intronic [location: chr3:182858302] and 1 at the $3^{\prime}$ UTR of LAMP3 [rs56682988, c. $\left.{ }^{*} 415 \mathrm{~T}>\mathrm{C}\right]$ ]) found only in controls (15 and 9 controls, respectively). To further examine whether these variants indeed drive the association in both BST1 and LAMP3, we excluded them and repeated the analysis (SKAT and SKAT-O), which resulted in loss of statistical significance for both genes (data available from Dryad, table e-6, doi.org/10.5061/dryad.vt4b8gtqd). There were no additional statistically significant associations of the remaining genes with iRBD after correction for multiple comparisons $(p$ $<0.001)$. We also repeated the analysis in 350 patients with available data on conversion who did not convert at the time of the study (data available from Dryad, table e-74). Rare functional and rare nonsynonymous BST1 variants were nominally associated with $\operatorname{iRBD}(p=0.021$ and $p=0.049$, SKAT) but not after correction for multiple comparisons. The association of LAMP3 had a value of $p=0.06$ (SKAT-O), demonstrating the reduced power in this smaller subpopulation.

\section{Structural Analysis of BST1 Variants Suggests That Loss of Function May Be Protective in iRBD}

To investigate the potential impact of the 3 BST1 nonsynonymous variants (p.V85M, p.I101V, and p.V272M) on the structure and activity of the enzyme, we performed in silico mutagenesis and evaluated potential clashes with surrounding residues. Figure depicts the structure of BST1 with the respective locations of the 3 nonsynonymous variants that drive the BST1 association detected in our analysis. The structure of human BST1 was solved by $\mathrm{x}$-ray crystallography in complex with 5 substrate analogs. ${ }^{26}$ All structures revealed a homodimeric assembly, with the catalytic clefts facing the cavity at the interface of the 2 chains (figure).

The side chain of $\mathrm{p} . \mathrm{V} 85 \mathrm{M}$ points toward the hydrophobic core of the protein, behind a helix facing the nucleotide binding site. The amino acid change from valine to the bulkier side chain of methionine results in clashes with other residues in the core for all rotamers (figure). This variant would therefore likely destabilize the enzyme active site and potentially unfold the protein. The side chain of the variant p.I101V is located underneath the active site toward the hydrophobic core. Although the amino acid change from isoleucine to the smaller side chain of valine does not create a clash (figure), it reduces the packing in the core, which could also destabilize the enzyme. Finally, the p.V272M variant is located in a helix at the $\mathrm{C}$-terminus of the protein that forms symmetric contacts with the same helix in the other chain of the dimer. The p.V272M variant would create clashes with side chain and main chain atoms located in the other chain of the dimer (figure). Because p.V272M resides at the dimer interface of the enzyme and probably helps maintain the 2 subunits together, this variant would most likely lead to the disruption of the dimer. Overall, all the disease-associated nonsynonymous variants in BST1 (p.V85M, p.I101V, and p.V272M) appear to be loss of function variants, suggesting that reduced BST1 activity may be protective in iRBD. This is supported by the top PD GWAS hit in the BST1 locus, the rs $4698412 \mathrm{G}$ allele, which is associated with reduced risk of PD. ${ }^{3}$ This allele is also associated with reduced expression of BST1 in blood in GTEx (normalized effect size $-0.07, p=1.5 \mathrm{e}-6$ ), suggesting that reduced expression might be protective.

\section{Very Rare Biallelic Variants Are Not Enriched in Patients With iRBD}

To examine whether biallelic variants in our genes of interest are enriched in $\mathrm{RBDD}$, we compared the carrier frequencies of very rare (MAF <0.001) homozygous and compound heterozygous variants between patients with $\mathrm{RBD}$ and controls. To analyze compound heterozygous variants, because phasing could not be performed, we considered carriers of 2 very rare variants as compound heterozygous carriers, with the following exceptions: (1) when variants were physically close $(<112 \mathrm{bp}$; target length of probes) and we could determine their phase from the sequence reads and (2) if the same combination of very rare variants appeared more than once across samples, in which case we assumed that the variants are most likely to be on the same allele. We found $5(0.5 \%)$ patients with iRBD and 7 (0.4\%) controls to presumably be carriers of biallelic variants in the studied genes $(p=0.731$, Fisher test, table 2).

\section{Association of Common Variants in the Target Genes With iRBD}

To test whether common variants in our target genes are associated with iRBD, we performed logistic regression (using PLINK version 1.9 software) adjusted for age and sex for common variants (MAF $>0.01$ ) detected at coverage depth of $>15 \times$. A nominal association was observed in 12 variants across all genes (data available from Dryad, table e-5, doi.org/ 10.5061/dryad.vt4b8gtqd), but no association remained statistically significant after Bonferroni correction for multiple comparisons (set at $p<0.0005$ ).

Of the variants with nominal associations, 1 variant in the ITGA8 3' UTR (rs896435, odds ratio 1.15, 95\% confidence interval 1.01-1.32, $p=0.04)$ is the top hit from the most recent PD GWAS, ${ }^{3}$ and 2 other ITGA8 $3^{\prime}$ UTR variants are almost in perfect $\mathrm{LD}\left(\mathrm{D}^{\prime}=1.0, R^{2}>0.99, p<0.0001\right)$ with rs896435. Four variants in the $3^{\prime}$ UTR of RAB29 were in almost perfect LD (data available from Dryad, table e-5, doi. org/10.5061/dryad.vt4b8gtqd) and are associated with 
Table 1 Summary of Results From Burden Analyses of Rare Heterozygous Variants

\begin{tabular}{|c|c|c|c|c|c|c|c|c|c|c|c|}
\hline \multirow[b]{3}{*}{ DOC } & \multirow[b]{3}{*}{ Gene } & \multicolumn{10}{|l|}{$p$ Value } \\
\hline & & \multicolumn{2}{|l|}{ All Rare } & \multicolumn{2}{|c|}{ Rare Functional } & \multicolumn{2}{|c|}{ Rare LOF } & \multicolumn{2}{|l|}{ Rare NS } & \multicolumn{2}{|c|}{ Rare CADD } \\
\hline & & SKAT-O & $\begin{array}{l}\text { SKAT } \\
\text { Burden }\end{array}$ & SKAT-O & $\begin{array}{l}\text { SKAT } \\
\text { Burden }\end{array}$ & SKAT-O & $\begin{array}{l}\text { SKAT } \\
\text { Burden }\end{array}$ & SKAT-O & $\begin{array}{l}\text { SKAT } \\
\text { Burden }\end{array}$ & SKAT-O & $\begin{array}{l}\text { SKAT } \\
\text { Burden }\end{array}$ \\
\hline \multirow[t]{25}{*}{$30 x$} & $A C M S D$ & 0.124 & 0.788 & 0.101 & 0.475 & NV & NV & 0.101 & 0.475 & 0.098 & 0.299 \\
\hline & $B S T I$ & 0.040 & 0.020 & $0.0009^{a}$ & $0.0004^{a}$ & 0.348 & 0.653 & 0.001 & $0.0007^{a}$ & 0.011 & 0.005 \\
\hline & $C C D C 62$ & 0.006 & 0.357 & 0.048 & 0.975 & 0.080 & 0.596 & 0.282 & 0.203 & 0.134 & 0.074 \\
\hline & $D D R G K 1$ & 0.152 & 0.112 & 0.745 & 0.527 & 0.765 & 0.587 & 0.746 & 0.742 & 0.919 & 0.677 \\
\hline & $D G K Q$ & 0.067 & 0.062 & 0.067 & 0.062 & NV & NV & 0.183 & 0.188 & NV & NV \\
\hline & FGF20 & 0.059 & 0.020 & 0.142 & 0.552 & 0.162 & 0.149 & 0.162 & 0.149 & 0.052 & 0.041 \\
\hline & GAK & 0.195 & 0.836 & 0.386 & 0.565 & 0.885 & 0.642 & 0.781 & 0.613 & 0.701 & 0.684 \\
\hline & GPNMB & 0.189 & 0.798 & 0.311 & 0.205 & 0.547 & 0.665 & 0.447 & 0.304 & 0.530 & 0.348 \\
\hline & HIP1R & 0.166 & 0.940 & 0.219 & 0.609 & NV & NV & 0.072 & 0.993 & 0.056 & 0.671 \\
\hline & ITGA8 & 0.282 & 0.726 & 0.379 & 0.945 & 0.346 & 0.648 & 0.382 & 0.997 & 0.288 & 0.873 \\
\hline & LAMP3 & $0.0006^{a}$ & 0.478 & 0.189 & 0.322 & 0.787 & 0.300 & 0.318 & 0.724 & 0.524 & 0.601 \\
\hline & MAPT & 0.063 & 0.132 & 0.003 & 0.001 & 1 & 1 & 0.063 & 0.037 & 0.165 & 0.101 \\
\hline & MCCC1 & 0.426 & 0.413 & 0.303 & 0.743 & 0.347 & 0.649 & 1 & 0.866 & 0.886 & 0.690 \\
\hline & PM20D1 & 0.333 & 0.463 & 0.844 & 0.643 & 0.674 & 0.464 & 0.645 & 0.479 & 0.569 & 0.416 \\
\hline & $R A B 25$ & 0.561 & 0.395 & 0.807 & 0.802 & 0.777 & 0.968 & 0.565 & 0.637 & NV & NV \\
\hline & $R A B 29$ & 0.252 & 0.222 & 0.660 & 0.425 & NV & NV & 0.777 & 0.967 & 0.777 & 0.967 \\
\hline & RIT2 & 0.395 & 0.242 & 0.023 & 0.266 & NV & NV & 0.576 & 0.495 & 0.576 & 0.495 \\
\hline & SETD1A & 0.667 & 0.500 & 0.241 & 0.452 & 0.171 & 0.166 & 0.300 & 0.940 & 0.310 & 0.399 \\
\hline & $S L C 41 A 1$ & 0.073 & 0.167 & 0.055 & 0.031 & 0.060 & 0.065 & 0.754 & 0.433 & 0.257 & 0.213 \\
\hline & STK39 & 0.098 & 0.789 & 0.055 & 0.094 & 0.174 & 0.171 & 0.160 & 0.247 & 0.160 & 0.247 \\
\hline & SIPA1L2 & 0.024 & 0.095 & 0.028 & 0.176 & 0.886 & 0.806 & 0.032 & 0.379 & 0.044 & 0.084 \\
\hline & STX1B & 0.504 & 0.682 & NV & NV & NV & NV & NV & NV & NV & NV \\
\hline & SYT11 & 0.365 & 0.887 & 0.737 & 0.582 & 1 & 1 & 0.673 & 0.465 & 0.673 & 0.465 \\
\hline & TMEM163 & 0.598 & 0.411 & 0.170 & 0.165 & NV & NV & 0.170 & 0.165 & 0.170 & 0.165 \\
\hline & USP25 & 0.012 & 0.325 & 0.102 & 0.150 & NV & NV & 0.048 & 0.067 & 0.052 & 0.096 \\
\hline \multirow[t]{11}{*}{$50 x$} & $A C M S D$ & 0.127 & 0.538 & 0.102 & 0.188 & NV & NV & 0.102 & 0.188 & 0.087 & 0.093 \\
\hline & BSTI & 0.018 & 0.009 & $0.0007^{a}$ & $0.0003^{a}$ & 0.671 & 0.470 & 0.001 & $0.0009^{a}$ & 0.010 & 0.006 \\
\hline & $C C D C 62$ & 0.011 & 0.012 & 0.031 & 0.018 & 0.056 & 0.047 & 0.027 & 0.014 & 0.005 & 0.004 \\
\hline & $D D R G K 1$ & 0.368 & 0.314 & 0.899 & 0.811 & NV & NV & 0.899 & 0.811 & 0.899 & 0.811 \\
\hline & $D G K Q$ & NV & NV & NV & NV & NV & NV & NV & NV & NV & NV \\
\hline & FGF2O & 0.015 & 0.030 & 0.164 & 0.153 & 0.164 & 0.153 & NV & NV & 0.164 & 0.153 \\
\hline & GAK & 0.195 & 0.836 & 0.386 & 0.565 & 0.885 & 0.642 & 0.781 & 0.613 & 0.701 & 0.684 \\
\hline & GPNMB & 0.046 & 0.995 & 0.177 & 0.127 & 0.108 & 0.413 & 0.343 & 0.215 & 0.283 & 0.189 \\
\hline & $H I P 1 R$ & NV & NV & NV & NV & NV & NV & NV & NV & NV & NV \\
\hline & ITGA8 & 0.184 & 0.315 & 0.402 & 0.540 & 0.340 & 0.634 & 0.428 & 0.584 & 0.345 & 0.942 \\
\hline & LAMP3 & 0.004 & 0.930 & 0.047 & 0.458 & 0.785 & 0.304 & 0.020 & 0.016 & 0.458 & 0.513 \\
\hline
\end{tabular}


Table 1 Summary of Results From Burden Analyses of Rare Heterozygous Variants (continued)

\begin{tabular}{|c|c|c|c|c|c|c|c|c|c|c|c|}
\hline \multirow[b]{3}{*}{ DOC } & \multirow[b]{3}{*}{ Gene } & \multicolumn{10}{|l|}{$p$ Value } \\
\hline & & \multicolumn{2}{|l|}{ All Rare } & \multicolumn{2}{|c|}{ Rare Functional } & \multicolumn{2}{|c|}{ Rare LOF } & \multicolumn{2}{|l|}{ Rare NS } & \multicolumn{2}{|c|}{ Rare CADD } \\
\hline & & SKAT-O & $\begin{array}{l}\text { SKAT } \\
\text { Burden }\end{array}$ & SKAT-O & $\begin{array}{l}\text { SKAT } \\
\text { Burden }\end{array}$ & SKAT-O & $\begin{array}{l}\text { SKAT } \\
\text { Burden }\end{array}$ & SKAT-O & $\begin{array}{l}\text { SKAT } \\
\text { Burden }\end{array}$ & SKAT-O & $\begin{array}{l}\text { SKAT } \\
\text { Burden }\end{array}$ \\
\hline & MAPT & 0.605 & 0.503 & 0.619 & 0.659 & NV & NV & 0.619 & 0.659 & 0.619 & 0.659 \\
\hline & $\mathrm{MCCC1}$ & 0.26 & 0.151 & 0.972 & 0.752 & 0.334 & 0.618 & 0.951 & 0.745 & 0.958 & 0.800 \\
\hline & PM20D1 & 0.903 & 0.934 & 0.873 & 0.758 & 0.662 & 0.487 & 1 & 0.758 & 0.816 & 0.666 \\
\hline & $R A B 25$ & 0.173 & 0.169 & NV & NV & NV & NV & NV & NV & NV & NV \\
\hline & $R A B 29$ & NV & NV & NV & NV & NV & NV & NV & NV & NV & NV \\
\hline & RIT2 & 0.953 & 0.874 & 0.667 & 0.478 & NV & NV & 0.667 & 0.478 & 0.667 & 0.478 \\
\hline & SETD1A & 0.212 & 0.147 & 0.671 & 0.469 & NV & NV & 0.671 & 0.469 & 0.671 & 0.469 \\
\hline & SLC41A1 & 0.132 & 0.189 & NV & NV & NV & NV & NV & NV & NV & NV \\
\hline & STK39 & 0.073 & 0.808 & 0.051 & 0.087 & 0.160 & 0.146 & 0.160 & 0.146 & 0.160 & 0.146 \\
\hline & SIPA1L2 & 0.163 & 0.098 & 0.598 & 0.861 & NV & NV & 0.777 & 0.963 & 0.777 & 0.963 \\
\hline & $S T X 1 B$ & NV & NV & NV & NV & NV & NV & NV & NV & NV & NV \\
\hline & SYT11 & 0.0896 & 0.671 & 0.672 & 0.467 & NV & NV & NV & NV & NV & NV \\
\hline & TMEM163 & 0.308 & 0.237 & 0.169 & 0.163 & NV & NV & 0.169 & 0.163 & 0.169 & 0.163 \\
\hline & USP25 & 0.127 & 0.418 & 0.027 & 0.019 & NV & NV & 0.027 & 0.019 & 0.069 & 0.037 \\
\hline
\end{tabular}

Abbreviations: $\mathrm{CADD}=$ Combined Annotation Dependent Depletion; $\mathrm{DOC}=$ depth of coverage; $\mathrm{LOF}=$ loss of function; $\mathrm{NS}=$ nonsynonymous; $\mathrm{NV}=$ no variants were found for this filter; SKAT = Kernel association test; SKAT-O = optimized sequence kernel association test.

The table shows $p$ values of the SKAT and SKAT-O analysis in the specified subgroups.

a Significant after Bonferroni correction for the number of genes and depths.

expression of RAB29 in multiple tissues in GTEx, including the brain. Three MAPT variants were in partial LD with PD GWAS hits in the MAPT locus and were associated with expression of multiple genes in multiple tissues in GTEx, demonstrating the complexity of this genomic region.

\section{Discussion}

In the current study, we studied a large cohort of patients with iRBD by fully sequencing and analyzing 25 PD-related GWAS genes and their association with iRBD. Our results identify $B S T 1$ and LAMP3 as novel genes potentially associated with iRBD. According to in silico models, the 3 nonsynonymous $B S T 1$ variants that drive the association with iRBD may be loss-of-function variants, suggesting that reduced BST1 activity may reduce the risk of developing iRBD. This hypothesis is further supported the results from the PD GWAS in which the BST1 locus variants associated with reduced risk of PD were also associated with reduced expression of BST1. ${ }^{3}$ Further studies will be required to determine that these variants are indeed loss-of-function variants and to study the mechanism underlying this potential protective association. The variants driving the association of LAMP3 are in noncoding regions and could be regulatory. These hypotheses will require confirmation in functional studies in relevant models.
While some common variants were nominally associated with $\mathrm{iRBD}$, none of them remained statistically significant after correction for multiple comparisons.

This study provides further support to our previous studies showing that there is only partial overlap between the genetics of $\mathrm{iRBD}$ and PD. Genes that are important in PD such as LRRK2 and MAPT seem to have no role in $\mathrm{iRBD},{ }^{10,11}$ whereas other genes such as GBA are important in both, as well as in DLB. ${ }^{5,8}$ However, we cannot rule out that some of the 25 genes that we tested in the current study are associated with iRBD, yet the effect size of the association is too small to detect with the current sample size. Therefore, additional studies in larger cohorts of iRBD will be required in the future to fully uncover the association between PD-related genes and iRBD.

BST1, also called CD157, is a glycosyl phosphatidylinositol anchored membrane protein initially found in bone marrow stromal cells and is essential for B-lymphocyte growth and development. It has an extracellular enzymatic domain that produces cADP-ribose. This metabolite acts as a second messenger that can trigger $\mathrm{Ca}^{2+}$ release from intracellular stores, ${ }^{27}$ a process that plays a role in cellular function and death. Specific features of calcium homeostasis have been 

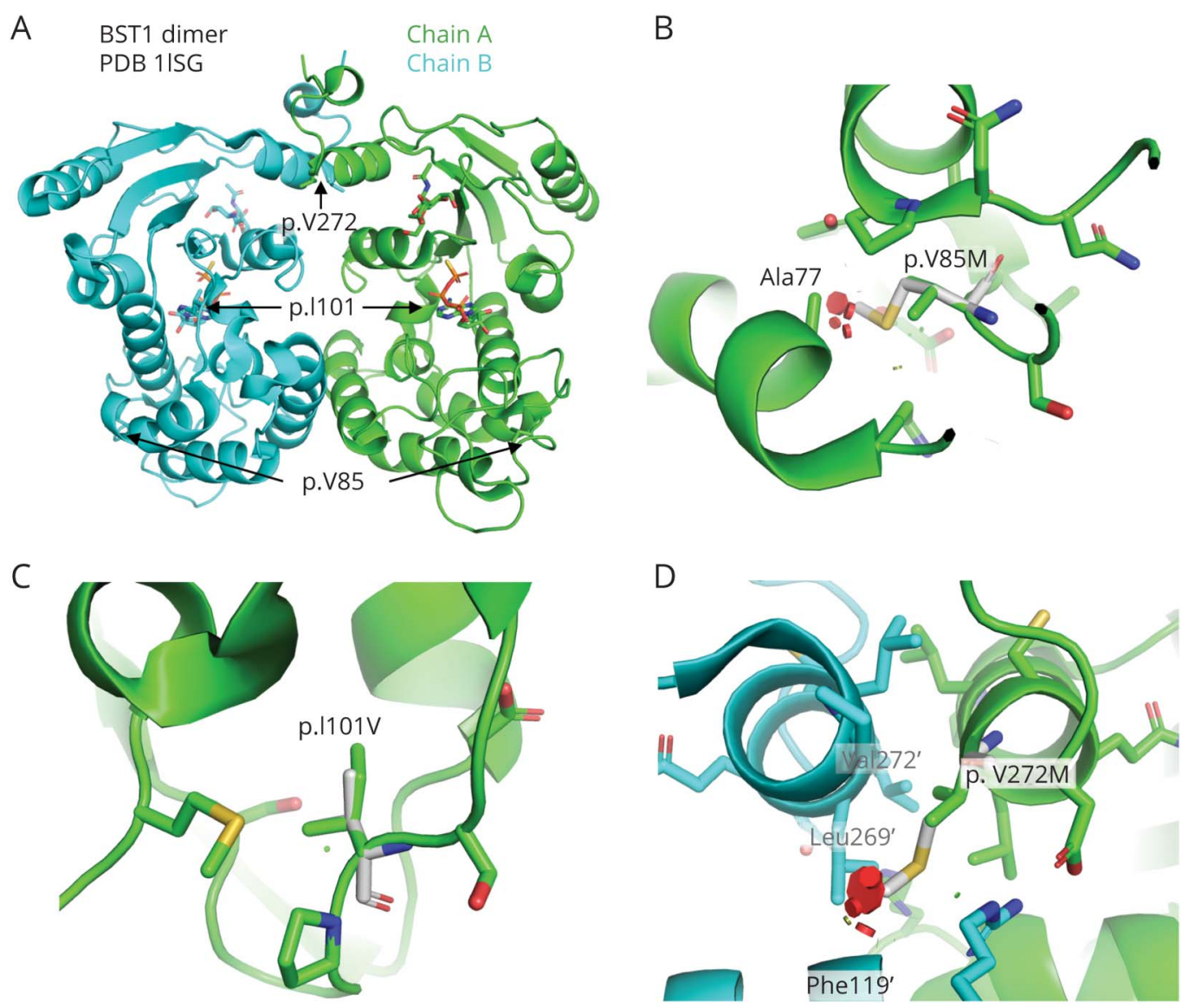

This figure was produced using PyMol software version 2.2.0 and represents the following. (A) Structure of the BST1 dimer bound to ATP-yS (pdb 1ISG). Position of each variant sites is indicated. ATP-yS molecule in the active site is shown as sticks. (B) Close-up view of the p.V85M variant site. Mutated residue is shown in white. Variant would create clashes (red disks) with nearby Ala77 in the core. (C) Close-up view of the p.1101V variant site. Residue is located in the core of the protein, but the variant to a smaller residue results in no clash. (D) Close-up view of the p.V272M variant site. Residues with a prime correspond to chain B. This residue is located at the dimer interface, and the variant would create clashes with the other chain, resulting in a destabilization of the dimer.

suggested to be responsible for the specific vulnerability of dopaminergic neurons in $\mathrm{PD},{ }^{28}$ yet whether BST1 is involved in calcium homeostasis in human neurons is still unclear because most work was done in nonhuman models. Other mechanisms by which BST1 may be involved in PD are immune response and neuroinflammation, which are likely important in the pathogenesis of the disease. BST1 serves as a receptor that regulates leukocyte adhesion and migration and plays a role in inflammation. ${ }^{29}$ However, its potential role in microglia activation and neuroinflammation is yet to be determined. Our in silico analysis suggested that the BST1 variants found mostly in controls are loss-of-function variants. Furthermore, common variants in the BST1 locus, carried by $>50 \%$ of the European population, are associated with reduced risk of PD in the most recent GWAS and are also associated with reduced expression of BST1 in blood, ${ }^{3}$ indicating that reduced BST1 expression may be protective. We can therefore hypothesize that these variants may reduce immune response and lead to a reduced risk of $\mathrm{RRBD}$ and that inhibition of BST1 could become a target for future preclinical drug discovery efforts for $\mathrm{iRBD}$ and $\mathrm{PD}$ treatment or prevention. Understanding the role of BST1 as an immune response gene in $\mathrm{iRBD}$, understanding the mechanism underlying this association, and examining whether it can serve as a target for early therapeutics development will require additional research in humans and different models.

LAMP3 encodes the lysosomal-associated membrane protein 3 , which plays a role in the unfolded protein response that contributes to protein degradation and cell survival during proteasomal dysfunction. ${ }^{30}$ Furthermore, LAMP3 knockdown impairs the ability of the cells to complete the autophagic process, and high LAMP3 expression is associated with increased basal autophagy levels. ${ }^{31}$ Numerous PD-related genes have been implicated in the autophagy-lysosomal pathway, ${ }^{32}$ and genes associated with iRBD such as $G B A,{ }^{33}$ TMEM175, ${ }^{34}$ and $S N C A^{14}$ are involved in this pathway. Our current findings further strengthen the potential association between the autophagy-lysosomal pathway and iRBD. The specific role of LAMP3 in this pathway and how it may be involved in $\mathrm{RBD}$ and the subsequent synucleinopathies will require additional studies. The rare variants we identified were 
Table 2 Summary of all Samples Carrying 2 Nonsynonymous Variants Detected in the Present Study

\begin{tabular}{|c|c|c|c|c|c|c|c|c|c|c|}
\hline Gene & Sample & Sex & AAS/AAO, y & dbSNP & Allele $^{a}$ & Substitution & F_A & F_C & gnomAD All & gnomAD NFE \\
\hline \multirow[t]{2}{*}{ GPNMB } & A & M & $75 / 50$ & 7:23300122 & $\mathrm{T} / \mathrm{C}$ & p.S250P & 0.000528 & 0 & - & - \\
\hline & & & & 7:23313795 & $\mathrm{G} / \mathrm{T}$ & p.Q545H & 0.0005285 & 0 & - & - \\
\hline \multirow[t]{2}{*}{ MAPT } & $A$ & M & $85 / 66$ & $17: 44051771$ & $\mathrm{G} / \mathrm{T}$ & p.D81Y & 0.0005656 & 0 & - & - \\
\hline & & & & rs63750612 & $\mathrm{G} / \mathrm{A}$ & p.A120T & 0.0005423 & 0 & 0.0035 & 7.17E-05 \\
\hline \multirow[t]{2}{*}{ SIPA1L2 } & $A$ & $\mathrm{~F}$ & $64 / 48$ & rs184013125 & $\mathrm{G} / \mathrm{A}$ & p.S1482L & 0.002665 & 0.008451 & 0.0057 & 0.0092 \\
\hline & & & & rs200917620 & $\mathrm{G} / \mathrm{A}$ & p.R1089W & 0.000547 & 0.000293 & $9.44 \mathrm{E}-05$ & 0.0002 \\
\hline \multirow[t]{2}{*}{ SIPA1L2 } & A & $\mathrm{F}$ & $66 /-$ & rs184013125 & $\mathrm{G} / \mathrm{A}$ & p.S1482L & 0.002665 & 0.008451 & 0.0057 & 0.0092 \\
\hline & & & & rs200293380 & $\mathrm{C} / \mathrm{T}$ & p.D1088N & 0.006031 & 0.004695 & 0.0028 & 0.0041 \\
\hline \multirow[t]{2}{*}{ USP25 } & $A$ & M & $68 /-$ & rs377694221 & $\mathrm{C} / \mathrm{T}$ & p.A56V & 0.000533 & 0 & 5.35E-05 & $7.23 \mathrm{E}-05$ \\
\hline & & & & rs200059109 & $\mathrm{G} / \mathrm{T}$ & p.D815Y & 0.000533 & 0 & 0.0002 & $1.90 \mathrm{E}-05$ \\
\hline \multirow[t]{2}{*}{ MCCC1 } & C & M & 35 & rs149017703 & $\mathrm{C} / \mathrm{T}$ & p.G648S & 0.001063 & 0.001683 & 0.0005 & 0.0009 \\
\hline & & & & $3: 182810207$ & $T / G$ & p.H88P & 0 & 0.0002804 & $8.12 \mathrm{E}-06$ & 8.95E-06 \\
\hline \multirow[t]{2}{*}{ PM20D1 } & $C$ & M & 50 & rs145195839 & $\mathrm{G} / \mathrm{A}$ & p.A332V & 0.001059 & 0.000844 & 0.0003 & 0.0004 \\
\hline & & & & rs14160575 & $\mathrm{G} / \mathrm{T}$ & p.P281Q & 0.005325 & 0.005936 & 0.0057 & 0.0058 \\
\hline \multirow[t]{2}{*}{ SIPA1L2 } & $C$ & M & 48 & $1: 232615440$ & & p.Y673F & 0 & 0.0002817 & - & - \\
\hline & & & & rs761063595 & & p.S266N & 0 & 0.0002817 & 4.07E-06 & 8.99E-06 \\
\hline \multirow[t]{2}{*}{ SIPA1L2 } & C & M & - & rs61729754 & $\mathrm{T} / \mathrm{G}$ & p.M1427L & 0.009062 & 0.005634 & 0.0058 & 0.0088 \\
\hline & & & & rs200293380 & $\mathrm{C} / \mathrm{T}$ & p.D1088N & 0.006031 & 0.004695 & 0.0028 & 0.0041 \\
\hline \multirow[t]{2}{*}{ SIPA1L2 } & C & M & 28 & rs184013125 & $\mathrm{G} / \mathrm{A}$ & p.S1482L & 0.002665 & 0.008451 & 0.0057 & 0.0092 \\
\hline & & & & $1: 232581435$ & $\mathrm{~T} / \mathrm{C}$ & p.T1065A & 0 & 0.000282 & - & - \\
\hline \multirow[t]{2}{*}{ SIPA1L2 } & C & M & 50 & rs184013125 & $\mathrm{G} / \mathrm{A}$ & p.S1482L & 0.002665 & 0.008451 & 0.0057 & 0.0092 \\
\hline & & & & rs966761148 & $\mathrm{C} / \mathrm{T}$ & p.V822M & 0 & 0.000282 & 2.03E-05 & $2.69 \mathrm{E}-05$ \\
\hline
\end{tabular}

Abbreviations: $A$ = affected; $A A O=$ age at onset of isolated REM sleep behavior disorder; $A A S=$ age at sampling; $C=$ control; $d b S N P=$ Single Nucleotide Polymorphism Database; F_A = frequency in affected; F_C = Frequency in controls; gnomAD = Genome Aggregation Database; NFE = non-Finnish Europe. The table represents all the carriers of biallelic nonsynonymous variants in the target genes.

a Allele: reference allele/mutant allele.

found only in controls, which may suggest that LAMP3 may have a protective effect that should be further explored.

Our study has several limitations. First, despite being the largest genetic study of iRBD to date, it may be still underpowered to detect rare variants in GWAS PD-related genes, as well as common variants with a small effect size. Therefore, we cannot completely rule out the possibility that rare and common variants in these genes may contribute to iRBD risk. A second limitation is the younger age and the differences in sex distribution between patients with iRBD and controls, for which we adjusted in the statistical analysis as needed. Another potential limitation is the possibility that there were patients with undiagnosed iRBD among the control population. However, because iRBD is found in only $\approx 1 \%$ of the population, ${ }^{1}$ the effect of having patients with undiagnosed $\mathrm{iRBD}$ in the controls would be minimal, given the large sample size. Additional limitation is the lack of replication cohort; therefore, our findings should be replicated in additional iRBD cohorts once they become available. Last, our study includes only individuals of European descent, and fully understanding the genetics of $i R B D$ will require studies with other ethnicities. Unfortunately, due to the reduced availability of polysomnography in many countries, there are currently only very few small cohorts of patients with iRBD from other populations, and more effort is required to develop such cohorts in different countries.

Our results suggest 2 novel genetic associations with $\mathrm{iRBD}$ : an association with rare functional variants in $B S T 1$ and with rare noncoding variants in $L A M P 3$. All the association-driving coding variants found in BST1, mainly in controls, appear to potentially cause loss of function, suggesting that reduced BST1 activity may reduce the risk of iRBD. Further studies 
would be required to confirm our results and to examine the biological mechanism underlying the effect of diseaseassociated variants in both LAMP3 and BST1. The absence of evidence of association between rare and common variants in the remaining genes and iRBD risk suggests that these genes either have no effect in iRBD or have a minor effect that we could not detect with this sample size. Environmental factors and environment-gene interactions are likely to play a major role on iRBD, and larger studies that include carefully collected epidemiologic data and more extensive genetic data such as whole-exome or whole-genome sequencing will be required to clarify these issues.

\section{Acknowledgment}

The authors thank the participants for contributing to this study. The authors thank D. Rochefort, H. Catoire, and V. Zaharieva for their assistance. J.Y. Montplaisir holds a Canada Research Chair in Sleep Medicine. J.-F. Gagnon holds a Canada Research Chair in Cognitive Decline in Pathological Aging. W. Oertel is Hertie Senior Research Professor, supported by the Hertie Foundation. G.A. Rouleau holds a Canada Research Chair in Genetics of the Nervous System and the Wilder Pen Field Chair in Neurosciences. J.F. Trempe holds a Canada Research Chair (tier 2) in Structural Pharmacology. Z. Gan-Or is supported by the Fonds de recherche du Québec-Santé Chercheur-Boursier award and is a Parkinson Canada New Investigator awardee.

\section{Study Funding}

This work was financially supported by the Michael J. Fox Foundation, the Canadian Consortium on Neurodegeneration in Aging, Parkinson Canada, the Canada First Research Excellence Fund, awarded to McGill University for the Healthy Brains for Healthy Lives program. The Montreal cohort was funded by the Canadian Institutes of Health Research (CIHR) and the W. Garfield Weston Foundation. The Oxford Discovery study is funded by the Monument Trust Discovery Award from Parkinson's UK and supported by the National Institute for Health Research (NIHR) Oxford Biomedical Research Centre based at Oxford University Hospitals NHS Trust and University of Oxford, the NIHR Clinical Research Network, and the Dementias and Neurodegenerative Diseases Research Network.

\section{Disclosure}

K. Mufti, E. Yu, U. Rudakou, L. Krohn, J.A. Ruskey, F. Asayesh, S.B. Laurent, and D. Spiegelman reports no conflict of interests to disclose. I. Arnulf received fees for speaking engagements from UCB pharma and consultancy fees from Roche, Novartis, and Ono Pharma. M.T.M. Hu received consultancy fees from Roche and Biogen Pharmaceuticals. J.Y. Montplaisir received consultancy fees from Eisai Co. J.-F. Gagnon reports research funding from the CIHR. A. Desautels received grants from Flamel Ireland, Pfized, Biron, and Canopy Growth, as well as fees for speaking engagements from Biogen and from consultancy from UCB Pharma. Y. Dauvilliers, G.L. Gigli, M. Valente, Francesco Janes, and A.
Bernardini report no conflict of interests to disclose. B. Högl received consultancy fees from Axovant, Benevolent Bio, Takeda, Roche, and Ono and received speaker honoraria from Eli Lilly, Mundipharma, UCB, Abbvie, Inspire, and Lundbeck. A. Stefani, E. Holzknecht, K. Sonka, and D. Kemlink report no conflict of interests to disclose. W. Oertel received consultancy or speaker fees from Adamas, Abbvie, Desitin, Novartis, and Roche. He has received research funding from the Deutsche Forschungsgemeinschaft (DFG), EU (Horizon2020), Parkinson Fonds Deutschland, Deutsche Parkinson Vereinigung, and Roche Pharma, Basel, Switzerland. A. Janzen has received research funding from Parkinson Fonds Deutschland. G. Plazzi, E. Antelmi, M. Figorilli, and M. Puligheddu report no conflict of interests to disclose. B. Mollenhauer has received honoraria for consultancy from Roche, Biogen, UCB, and Sun Pharma Advanced Research Company. B. Mollenhauer is member of the executive steering committee of the Parkinson Progression Marker Initiative and principal investigator of the Systemic Synuclein Sampling Study of the Michael J. Fox Foundation for Parkinson's Research and has received research funding from the Deutsche Forschungsgemeinschaft (DFG), EU (Horizon2020), Parkinson Fonds Deutschland, Deutsche Parkinson Vereinigung, and the Michael J. Fox Foundation for Parkinson's Research. C. Trenkwalder reports honoraria for lectures from UCB, Grünenthal, and Otsuka and consultancy fees from Britannia Pharmaceuticals and Roche. F. Sixel-Döring reports honoraria for lectures from Abbott, Desitin, Grünenthal, Licher MT, STADA Pharm, and UCB; reports seminar fees from Boston Scientific and Licher MT and serves on an advisory board for STADA Pharm. V. Cochen De Cock, C.C. Monaca, A. Heidbreder, L. Ferini-Strambi, F. Dijkstra, M. Viaene, and B. Abril report no conflict of interests to disclose. B.F. Boeve has served as an investigator for clinical trials sponsored by Biogen and Alector. He serves on the Scientific Advisory Board of the Tau Consortium. He receives research support from the NIH, the Mayo Clinic Dorothy and Harry T. Mangurian Jr. Lewy Body Dementia Program, the Little Family Foundation, and the LBD Functional Genomics Program. J.-F. Trempe and G.A. Rouleau report no conflict of interests to disclose. R.B. Postuma reports grants and Fonds de la Recherche en Sante, as well as grants from the CIHR, The Parkinson Society of Canada, the WestonGarfield Foundation, the Michael J. Fox Foundation, and the Webster Foundation, as well as personal fees from Takeda, Roche, Teva Neurosciences, Novartis Canada, Biogen, Boehringer Ingelheim, Theranexus, GE HealthCare, Jazz Pharmaceuticals, Abbvie, Jannsen, Otsuko, Phytopharmics, and Inception Sciences. Z. Gan-Or received consultancy fees from Lysosomal Therapeutics Inc, Idorsia, Prevail Therapeutics, Inceptions Sciences (now Ventus), Ono Therapeutics, Denali, Handl Therapeutics, Neuron23, and Deerfield. Go to Neurology.org/N for full disclosures.

\section{Publication History}

Received by Neurology July 23, 2020. Accepted in final form December 2, 2020. 
Appendix Authors

\begin{tabular}{lll}
\hline Name & Location & Contribution \\
\hline $\begin{array}{l}\text { Kheireddin } \\
\text { Mufti, MSc }\end{array}$ & $\begin{array}{l}\text { McGill University, } \\
\text { Quebec, Canada }\end{array}$ & $\begin{array}{l}\text { Designed and } \\
\text { conceptualized study; } \\
\text { analyzed the data; drafted } \\
\text { the manuscript for } \\
\text { intellectual content }\end{array}$ \\
\hline $\begin{array}{l}\text { Eric Yu, BSc, } \\
\text { MSc }\end{array}$ & $\begin{array}{l}\text { McGill University, } \\
\text { Quebec, Canada }\end{array}$ & $\begin{array}{l}\text { Analyzed the data; revised } \\
\text { the manuscript for } \\
\text { intellectual content }\end{array}$ \\
\hline $\begin{array}{l}\text { Uladzislau } \\
\text { Rudakou, MSc }\end{array}$ & McGill University, & $\begin{array}{l}\text { Analyzed the data; revised } \\
\text { the manuscript for } \\
\text { intellectual content }\end{array}$ \\
\hline $\begin{array}{l}\text { Lynne Krohn, } \\
\text { MSc }\end{array}$ & $\begin{array}{l}\text { McGill University, } \\
\text { Quebec, Canada }\end{array}$ & $\begin{array}{l}\text { Analyzed the data; revised } \\
\text { the manuscript for } \\
\text { intellectual content }\end{array}$ \\
\hline $\begin{array}{l}\text { Jennifer A. } \\
\text { Ruskey, MSc }\end{array}$ & $\begin{array}{l}\text { McGill University, } \\
\text { Quebec, Canada }\end{array}$ & $\begin{array}{l}\text { Major role in the acquisition } \\
\text { of data; revised the } \\
\text { manuscript for intellectual } \\
\text { content }\end{array}$ \\
\hline
\end{tabular}

\begin{tabular}{lll}
\hline $\begin{array}{l}\text { Farnaz } \\
\text { Asayesh, MSc }\end{array}$ & $\begin{array}{l}\text { McGill University, } \\
\text { Quebec, Canada }\end{array}$ & $\begin{array}{l}\text { Major role in the acquisition of } \\
\text { data; revised the manuscript } \\
\text { for intellectual content }\end{array}$ \\
\hline $\begin{array}{l}\text { Sandra B. } \\
\text { Laurent, BTS }\end{array}$ & $\begin{array}{l}\text { McGill University, } \\
\text { Quebec, Canada }\end{array}$ & $\begin{array}{l}\text { Major role in the acquisition of } \\
\text { data; revised the manuscript } \\
\text { for intellectual content }\end{array}$ \\
\hline $\begin{array}{l}\text { Dan } \\
\text { Spiegelman, } \\
\text { MSc }\end{array}$ & $\begin{array}{l}\text { McGill University, } \\
\text { Quebec, Canada }\end{array}$ & $\begin{array}{l}\text { Major role in the acquisition } \\
\text { of data; revised the } \\
\text { manuscript for intellectual } \\
\text { content }\end{array}$ \\
$\begin{array}{l}\text { Isabelle Arnulf, } \\
\text { MD, PhD }\end{array}$ & $\begin{array}{l}\text { Moelle Epinière and } \\
\text { Sorbonne Universities, } \\
\text { Paris, France }\end{array}$ & $\begin{array}{l}\text { Major role in the acquisition } \\
\text { of data; revised the } \\
\text { manuscript for intellectual } \\
\text { content }\end{array}$ \\
\hline
\end{tabular}

\begin{tabular}{lll}
\hline Michele T.M. & Oxford University, UK & $\begin{array}{l}\text { Major role in the acquisition } \\
\text { of data; revised the } \\
\text { mu, MBBS, PhD }\end{array}$ \\
& & conteript for intellectual
\end{tabular}

\begin{tabular}{|c|c|c|}
\hline $\begin{array}{l}\text { Jacques Y. } \\
\text { Montplaisir, } \\
\text { MD, PhD }\end{array}$ & $\begin{array}{l}\text { Université de } \\
\text { Montréal, Quebec, } \\
\text { Canada }\end{array}$ & $\begin{array}{l}\text { Major role in the acquisition } \\
\text { of data; revised the } \\
\text { manuscript for intellectual } \\
\text { content }\end{array}$ \\
\hline $\begin{array}{l}\text { Jean-François } \\
\text { Gagnon, PhD }\end{array}$ & $\begin{array}{l}\text { Hôpital du Sacré-Cœur } \\
\text { de Montréal, Quebec, } \\
\text { Canada }\end{array}$ & $\begin{array}{l}\text { Major role in the acquisition } \\
\text { of data; revised the } \\
\text { manuscript for intellectual } \\
\text { content }\end{array}$ \\
\hline $\begin{array}{l}\text { Alex Desautels, } \\
\text { MD, PhD }\end{array}$ & $\begin{array}{l}\text { Université de } \\
\text { Montréal, Quebec, } \\
\text { Canada }\end{array}$ & $\begin{array}{l}\text { Major role in the acquisition } \\
\text { of data; revised the } \\
\text { manuscript for intellectual } \\
\text { content }\end{array}$ \\
\hline $\begin{array}{l}\text { Yves } \\
\text { Dauvilliers, } \\
\text { MD, PhD }\end{array}$ & $\begin{array}{l}\text { University of } \\
\text { Montpellier, France }\end{array}$ & $\begin{array}{l}\text { Major role in the acquisition } \\
\text { of data; revised the } \\
\text { manuscript for intellectual } \\
\text { content }\end{array}$ \\
\hline $\begin{array}{l}\text { Gian Luigi Gigli, } \\
\text { MD }\end{array}$ & $\begin{array}{l}\text { University Hospital of } \\
\text { Udine, Italy }\end{array}$ & $\begin{array}{l}\text { Major role in the acquisition } \\
\text { of data; revised the } \\
\text { manuscript for intellectual } \\
\text { content }\end{array}$ \\
\hline $\begin{array}{l}\text { Mariarosaria } \\
\text { Valente, MD }\end{array}$ & $\begin{array}{l}\text { University Hospital of } \\
\text { Udine, Italy }\end{array}$ & $\begin{array}{l}\text { Major role in the acquisition of } \\
\text { data; revised the manuscript } \\
\text { for intellectual content }\end{array}$ \\
\hline
\end{tabular}

Appendix (continued)

\begin{tabular}{lll}
\hline Name & Location & Contribution \\
\hline $\begin{array}{l}\text { Francesco } \\
\text { Janes, MD, PhD }\end{array}$ & $\begin{array}{l}\text { University Hospital of } \\
\text { Udine, Italy }\end{array}$ & $\begin{array}{l}\text { Major role in the acquisition } \\
\text { of data; revised the } \\
\text { manuscript for intellectual } \\
\text { content }\end{array}$ \\
\hline $\begin{array}{l}\text { Andrea } \\
\text { Bernardini, MD }\end{array}$ & $\begin{array}{l}\text { University Hospital of } \\
\text { Udine, Italy }\end{array}$ & $\begin{array}{l}\text { Major role in the acquisition } \\
\text { of data; revised the } \\
\text { manuscript for intellectual } \\
\text { content }\end{array}$ \\
\hline Birgit Högl, MD & $\begin{array}{l}\text { Medical University of } \\
\text { Innsbruck, Austria }\end{array}$ & $\begin{array}{l}\text { Major role in the acquisition } \\
\text { of data; revised the } \\
\text { manuscript for intellectual } \\
\text { content }\end{array}$ \\
\hline $\begin{array}{l}\text { Ambra Stefani, } \\
\text { MD }\end{array}$ & $\begin{array}{l}\text { Medical University of } \\
\text { Innsbruck, Austria }\end{array}$ & $\begin{array}{l}\text { Major role in the acquisition } \\
\text { of data; revised the } \\
\text { manuscript for intellectual } \\
\text { content }\end{array}$ \\
\hline
\end{tabular}

\begin{tabular}{lll}
\hline Evi Holzknecht, & Medical University of \\
MD & Innsbruck, Austria & $\begin{array}{l}\text { Major role in the acquisition } \\
\text { of data; revised the } \\
\text { manuscript for intellectual } \\
\text { content }\end{array}$
\end{tabular}

\begin{tabular}{lll}
\hline Karel Sonka, & Charles University, & Major role in the acquisition \\
MD, PhD & Prague, Czech & of data; revised the \\
& Republic & $\begin{array}{l}\text { manuscript for intellectual } \\
\text { content }\end{array}$
\end{tabular}

David Kemlink, Charles University, Major role in the acquisition MD, PhD Prague, Czech of data; revised the Republic manuscript for intellectual content

\begin{tabular}{lll}
\hline Wolfgang & Philipps University, & Major role in the acquisition \\
Oertel, MD & Marburg, Germany & $\begin{array}{l}\text { of data; revised the } \\
\text { manuscript for intellectual } \\
\text { content }\end{array}$ \\
\end{tabular}

\begin{tabular}{lll}
\hline $\begin{array}{l}\text { Annette } \\
\text { Janzen, MD }\end{array}$ & Philipps University, & Major role in the acquisition \\
Marburg, Germany & $\begin{array}{l}\text { of data; revised the } \\
\text { manuscript for intellectual } \\
\text { content }\end{array}$
\end{tabular}

\begin{tabular}{lll}
\hline Giuseppe & University of Bologna, & Major role in the acquisition \\
Plazzi, MD & Italy & $\begin{array}{l}\text { of data; revised the } \\
\text { manuscript for intellectual } \\
\text { content }\end{array}$
\end{tabular}

Elena Antelmi, University of Bologna, Major role in the acquisition MD, PhD Italy of data; revised the manuscript for intellectual content

\begin{tabular}{lll}
\hline Michela & University of Cagliari, & Major role in the acquisition \\
Figorilli, MD, & Italy & of data; revised the \\
PhD & & manuscript for intellectual \\
& content
\end{tabular}

\begin{tabular}{lll}
\hline $\begin{array}{l}\text { Monica } \\
\text { Puligheddu, }\end{array}$ & University of Cagliari, & $\begin{array}{l}\text { Major role in the acquisition } \\
\text { of data; revised the } \\
\text { MD, PhD }\end{array}$ \\
& $\begin{array}{l}\text { manuscript for intellectual } \\
\text { content }\end{array}$ \\
\hline
\end{tabular}

\begin{tabular}{lll}
\hline $\begin{array}{l}\text { Brit } \\
\text { Mollenhauer, } \\
\text { MD }\end{array}$ & $\begin{array}{l}\text { University Medical } \\
\text { Centre Göttingen, } \\
\text { Germany }\end{array}$ & $\begin{array}{l}\text { Major role in the acquisition } \\
\text { of data; revised the } \\
\text { manuscript for intellectual } \\
\text { content }\end{array}$ \\
\hline $\begin{array}{l}\text { Claudia } \\
\text { Mrenkwalder, }\end{array}$ & $\begin{array}{l}\text { University Medical } \\
\text { Centre Göttingen, } \\
\text { Germany }\end{array}$ & $\begin{array}{l}\text { Major role in the acquisition } \\
\text { of data; revised the } \\
\text { manuscript for intellectual } \\
\text { content. }\end{array}$
\end{tabular}

Continued 
Appendix (continued)

\begin{tabular}{lll}
\hline Name & Location & Contribution \\
\hline $\begin{array}{l}\text { Friederike } \\
\text { Sixel-Döring, } \\
\text { MD }\end{array}$ & $\begin{array}{l}\text { University Medical } \\
\text { Centre Göttingen, } \\
\text { Germany }\end{array}$ & $\begin{array}{l}\text { Major role in the acquisition } \\
\text { of data; revised the } \\
\text { manuscript for intellectual } \\
\text { content }\end{array}$ \\
\hline $\begin{array}{l}\text { Valérie Cochen } \\
\text { De Cock, MD, } \\
\text { PhD }\end{array}$ & $\begin{array}{l}\text { University Medical } \\
\text { Centre Göttingen, }\end{array}$ & $\begin{array}{l}\text { Major role in the acquisition } \\
\text { of data; revised the } \\
\text { manuscript for intellectual } \\
\text { content }\end{array}$ \\
$\begin{array}{l}\text { Ghristelle } \\
\text { Charley } \\
\text { Monaca, MD }\end{array}$ & $\begin{array}{l}\text { University Lille North } \\
\text { of France, France }\end{array}$ & $\begin{array}{l}\text { Major role in the acquisition } \\
\text { of data; revised the } \\
\text { manuscript for intellectual } \\
\text { content }\end{array}$ \\
\hline
\end{tabular}

\begin{tabular}{lll}
\hline $\begin{array}{l}\text { Anna } \\
\text { Heidbreder, }\end{array}$ & University of & Müenster, Germany \\
MD & & $\begin{array}{l}\text { Major role in the acquisition } \\
\text { of data; revised the } \\
\text { manuscript for intellectual } \\
\text { content }\end{array}$ \\
\hline
\end{tabular}

\begin{tabular}{lll}
\hline Luigi Ferini- & Università Vita-Salute & $\begin{array}{l}\text { Major role in the acquisition } \\
\text { Strambi, MD }\end{array}$ \\
& San Raffaele, Milan, & $\begin{array}{l}\text { of data; revised the } \\
\text { Italy }\end{array}$ \\
& manuscript for intellectual
\end{tabular}
content

\begin{tabular}{lll}
\hline Femke & St. Dimpna Regional & Major role in the acquisition \\
Dijkstra, MD & $\begin{array}{l}\text { Hospital, Geel, } \\
\text { Belgium }\end{array}$ & $\begin{array}{l}\text { of data; revised the } \\
\text { manuscript for intellectual } \\
\text { content }\end{array}$
\end{tabular}

Mineke Viaene, St. Dimpna Regional Major role in the acquisition MD, PhD Hospital, Geel, of data; revised the Belgium manuscript for intellectual content

\begin{tabular}{lll}
\hline Beatriz Abril, & University Hospital of & $\begin{array}{l}\text { Major role in the acquisition } \\
\text { of data; revised the } \\
\text { MD }\end{array}$ \\
& $\begin{array}{l}\text { manuscript for intellectual } \\
\text { content }\end{array}$
\end{tabular}

Bradley F. Mayo Clinic,

Boeve, MD Rochester, MN

Major role in the acquisition of data; revised the manuscript for intellectual content

\begin{tabular}{lll}
\hline Jean-François & McGill University, & Analyzed the data; revised \\
Trempe, PhD & Quebec, Canada & the manuscript for \\
intellectual content
\end{tabular}

\begin{tabular}{lll}
\hline Guy A. & McGill University, & Major role in the acquisition \\
Rouleau, MD, & Quebec, Canada & of data; revised the \\
PhD, FRCPC, & & manuscript for intellectual
\end{tabular}

FRSC

\begin{tabular}{lll}
\hline $\begin{array}{l}\text { Ronald B. } \\
\text { Postuma, MD, } \\
\text { MSc }\end{array}$ & $\begin{array}{l}\text { McGill University, } \\
\text { Quebec, Canada }\end{array}$ & $\begin{array}{l}\text { Major role in the acquisition } \\
\text { of data; revised the } \\
\text { manuscript for intellectual } \\
\text { content }\end{array}$ \\
\hline $\begin{array}{l}\text { Ziv Gan-Or, MD, } \\
\text { PhD }\end{array}$ & McGill University, & $\begin{array}{l}\text { Designed and conceptualized } \\
\text { study; major role in the } \\
\text { acquisition of data; } \\
\text { performed statistical analysis; } \\
\text { drafted the manuscript for } \\
\text { intellectual content }\end{array}$ \\
& &
\end{tabular}

\section{References}

1. Postuma RB, Iranzo A, Hu M, et al. Risk and predictors of dementia and parkinsonism in idiopathic REM sleep behaviour disorder: a multicentre study. Brain 2019;142:744-759.

2. Iranzo A, Santamaria J, Tolosa E. Idiopathic rapid eye movement sleep behaviour disorder: diagnosis, management, and the need for neuroprotective interventions. Lancet Neurol 2016;15:405-419.
3. Nalls MA, Blauwendraat C, Vallerga CL, et al. Expanding Parkinson's disease genetics: novel risk loci, genomic context, causal insights and heritable risk. BioRxiv 2019: 388165.

4. Foo JN, Chew EGY, Chung SJ, et al. Identification of risk loci for Parkinson disease in Asians and comparison of risk between Asians and Europeans: a genome-wide association study. JAMA Neurol 2020;77:746-754

5. Gan-Or Z, Rouleau GA. Genetics of REM sleep behavior disorder. In: Rapid-EyeMovement Sleep Behavior Disorder. Berlin: Springer; 2019:589-609.

6. Gan-Or Z, Alcalay RN, Rouleau GA, Postuma RB. Sleep disorders and Parkinson disease: lessons from genetics. Sleep Med Rev 2018;41:101-112.

7. Blauwendraat C, Nalls MA, Singleton AB. The genetic architecture of Parkinson's disease. Lancet Neurol 2020;19:170-178.

8. Gan-Or Z, Mirelman A, Postuma RB, et al. GBA mutations are associated with rapid eye movement sleep behavior disorder. Ann Clin Transl Neurol 2015;2:941-945.

9. Heckman MG, Soto-Ortolaza AI, Contreras MYS, et al. LRRK2 variation and dementia with Lewy bodies. Parkinsonism Relat Disord 2016;31:98-103.

10. Bencheikh BOA, Ruskey JA, Arnulf I, et al. LRRK2 protective haplotype and full sequencing study in REM sleep behavior disorder. Parkinsonism Relat Disord 2018; 52:98-101.

11. Li J, Ruskey JA, Arnulf I, et al. Full sequencing and haplotype analysis of MAPT in Parkinson's disease and rapid eye movement sleep behavior disorder. Mov Disord 2018;33:1016-1020.

12. Dickson DW, Heckman MG, Murray ME, et al. APOE $\varepsilon 4$ is associated with severity of Lewy body pathology independent of Alzheimer pathology. Neurology 2018;91: e1182-e1195.

13. Gan-Or Z, Montplaisir JY, Ross JP, et al. The dementia-associated APOE $\varepsilon 4$ allele is not associated with rapid eye movement sleep behavior disorder. Neurobiol Aging 2017;49:218.e213-218.e215.

14. Krohn L, Wu RY, Heilbron K, et al. Fine-mapping of SNCA in rapid eye movement sleep behavior disorder and overt synucleinopathies. Ann Neurol 2020;87:584-598.

15. Mufti K, Rudakou U, Yu E, et al. A comprehensive analysis of dominant and recessive parkinsonism genes in REM sleep behavior disorder. medRxiv 2020.

16. Nalls MA, Pankratz N, Lill CM, et al. Large-scale meta-analysis of genome-wide association data identifies six new risk loci for Parkinson's disease. Nat Genet 2014;46: 989.

17. Chang D, Nalls MA, Hallgrímsdóttir IB, et al. A meta-analysis of genome-wide association studies identifies 17 new Parkinson's disease risk loci. Nat Genet 2017;49: 1511.

18. O'Roak BJ, Vives L, Fu W, et al. Multiplex targeted sequencing identifies recurrently mutated genes in autism spectrum disorders. Science 2012;338:1619-1622.

19. Li H, Durbin R. Fast and accurate short read alignment with Burrows-Wheeler transform. Bioinformatics 2009;25:1754-1760

20. McKenna A, Hanna M, Banks E, et al. The Genome Analysis Toolkit: a MapReduce framework for analyzing next-generation DNA sequencing data. Genome Res 2010; 20:1297-1303.

21. Wang $\mathrm{K}, \mathrm{Li} \mathrm{M}, \mathrm{Hak}$ anarson $\mathrm{H}$. ANNOVAR: functional annotation of genetic variants from high-throughput sequencing data. Nucleic Acids Res 2010;38:e164.

22. Lek M, Karczewski KJ, Minikel EV, et al. Analysis of protein-coding genetic variation in 60,706 humans. Nature 2016;536:285-291.

23. Purcell S, Neale B, Todd-Brown K, et al. PLINK: a tool set for whole-genome association and population-based linkage analyses. Am J Hum Genet 2007;81: $559-575$.

24. Lee S, Emond MJ, Bamshad MJ, et al. Optimal unified approach for rare-variant association testing with application to small-sample case-control whole-exome sequencing studies. Am J Hum Genet 2012;91:224-237.

25. Machiela MJ, Chanock SJ. LDlink: a web-based application for exploring populationspecific haplotype structure and linking correlated alleles of possible functional variants. Bioinformatics 2015;31:3555-3557.

26. Yamamoto-Katayama S, Ariyoshi M, Ishihara K, Hirano T, Jingami H, Morikawa K. Crystallographic studies on human BST-1/CD157 with ADP-ribosyl cyclase and NAD glycohydrolase activities. J Mol Biol 2002;316:711-723.

27. Ishihara K, Hirano T. BST-1/CD157 regulates the humoral immune responses in vivo. Chem Immunol 2000;75:235-255.

28. Chan CS, Gertler TS, Surmeier DJ. Calcium homeostasis, selective vulnerability and Parkinson's disease. Trends Neurosciences 2009;32:249-256.

29. Malavasi F, Deaglio S, Ferrero E, et al. CD38 and CD157 as receptors of the immune system: a bridge between innate and adaptive immunity. Mol Med 2006; 12:334-341.

30. Dominguez-Bautista JA, Klinkenberg M, Brehm N, et al. Loss of lysosome-associated membrane protein 3 (LAMP3) enhances cellular vulnerability against proteasomal inhibition. Eur J Cel Biol 2015;94:148-161.

31. Nagelkerke A, Sieuwerts AM, Bussink J, et al. LAMP3 is involved in tamoxifen resistance in breast cancer cells through the modulation of autophagy. Endocr Relat Cancer 2014;21:101-112

32. Senkevich K, Gan-Or Z. Autophagy lysosomal pathway dysfunction in Parkinson's disease; evidence from human genetics. Parkinsonism Relat Disord 2019;73:60-71.

33. Krohn L, Ruskey JA, Rudakou U, et al. GBA variants in REM sleep behavior disorder a multicenter study. Neurology 2020;95:e1008-e1016.

34. Krohn L, Öztürk TN, Vanderperre B, et al. Genetic, structural, and functional evidence link TMEM175 to synucleinopathies. Ann Neurol 2020;87:139-153. 


\section{Neurology}

\section{Novel Associations of BST1 and LAMP3 With REM Sleep Behavior Disorder}

Kheireddin Mufti, Eric Yu, Uladzislau Rudakou, et al.

Neurology 2021;96;e1402-e1412 Published Online before print January 4, 2021

DOI 10.1212/WNL.0000000000011464

This information is current as of January 4, 2021

\section{Updated Information \&} Services

\section{References}

Subspecialty Collections

Permissions \& Licensing

Reprints including high resolution figures, can be found at: http://n.neurology.org/content/96/10/e1402.full

This article cites 31 articles, 5 of which you can access for free at: http://n.neurology.org/content/96/10/e1402.full\#ref-list-1

This article, along with others on similar topics, appears in the following collection(s):

Association studies in genetics

http://n.neurology.org/cgi/collection/association_studies_in_genetics Case control studies

http://n.neurology.org/cgi/collection/case_control_studies

Parasomnias

http://n.neurology.org/cgi/collection/parasomnias

Parkinson's disease/Parkinsonism

http://n.neurology.org/cgi/collection/parkinsons_disease_parkinsonism

Information about reproducing this article in parts (figures,tables) or in its entirety can be found online at:

http://www.neurology.org/about/about_the_journal\#permissions

Information about ordering reprints can be found online:

http://n.neurology.org/subscribers/advertise

Neurology $\mathbb{B}$ is the official journal of the American Academy of Neurology. Published continuously since 1951, it is now a weekly with 48 issues per year. Copyright Copyright @ 2021 The Author(s). Published by Wolters Kluwer Health, Inc. on behalf of the American Academy of Neurology.. All rights reserved. Print ISSN: 0028-3878. Online ISSN: 1526-632X.

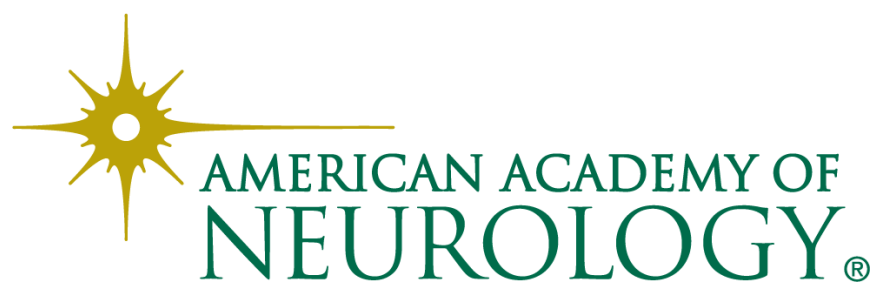

